\title{
The Communications Decency Act: Immunity for Internet- Facilitated Commercial Sexual Exploitation
}

Haley C. Halverson

National Center on Sexual Exploitation, haley@ncose.com

Follow this and additional works at: https://digitalcommons.uri.edu/dignity

Part of the Communications Law Commons, Communication Technology and New Media Commons, Gender and Sexuality Commons, Law and Gender Commons, Law and Politics Commons, Law and Society Commons, Legal History Commons, Legal Writing and Research Commons, Rule of Law Commons, and the Sexuality and the Law Commons

\section{Recommended Citation}

Halverson, Haley C. (2018) "The Communications Decency Act: Immunity for Internet-Facilitated Commercial Sexual Exploitation," Dignity: A Journal of Analysis of Exploitation and Violence: Vol. 3: Iss. 1, Article 12. https://doi.org/10.23860/dignity.2018.03.01.12

This Research and Scholarly Article is brought to you for free and open access by DigitalCommons@URI. It has been accepted for inclusion in Dignity: A Journal of Analysis of Exploitation and Violence by an authorized editor of DigitalCommons@URI. For more information, please contact digitalcommons@etal.uri.edu. 


\title{
The Communications Decency Act: Immunity for Internet-Facilitated Commercial Sexual Exploitation
}

\author{
Abstract \\ This paper reviews the original intent and historical application of the Communications Decency Act \\ (CDA), most notably Section 230, with special regard to cases of Internet-facilitated commercial sexual \\ exploitation. Although the CDA was originally created to protect children online, Section 230 of the CDA \\ has been interpreted by the courts to grant broad immunities to websites facilitating the sexual \\ exploitation of children and adults alike. Through analyzing the genesis and evolution of the CDA, it \\ becomes clear that court interpretations of Section 230 are starkly inconsistent with original \\ Congressional intent, and that the primary way to avoid de facto decriminalization of Internet-facilitated \\ commercial sexual exploitation is to amend the Communications Decency Act.
}

\section{Keywords}

United States, communications decency act (CDA), law, legislative history, sexual exploitation, sex trafficking, craigslist, backpage

\section{Creative Commons License} (c) (i) $\ominus$

This work is licensed under a Creative Commons Attribution-Noncommercial-No Derivative Works 4.0 License.

\section{Acknowledgements}

I would like to thank my family and colleagues at the National Center on Sexual Exploitation, for their continued support. Dignity thanks the following people for their time and expertise in reviewing this article: Mary Graw Leary, Professor of Law, The Catholic University of America; Christopher R. Green, Associate Professor of Law and H. L. A. Hart Scholar in Law and Philosophy, University of Mississippi School of Law; and Donna Rice Hughes, CEO and President of Enough Is Enough, USA. 


\section{DIGNITY}

Volume 3, Issue 1, Article 12, 2018
A JOURNAL ON

SEXUAL EXPLOITATION

AND VIOLENCE

\title{
THE COMMUNICATIONS DECENCY ACT: IMMUNITY FOR INTERNET-FACILITATED COMMERCIAL SEXUAL EXPLOITATION
}

\author{
Haley C. Halverson \\ National Center on Sexual Exploitation
}

\begin{abstract}
This paper reviews the original intent and historical application of the Communications Decency Act (CDA), most notably section 230, with special regard to cases of Internetfacilitated commercial sexual exploitation. Although the CDA was originally created to protect children online, section 230 of the CDA has been interpreted by the courts to grant broad immunities to websites facilitating the sexual exploitation of children and adults alike. Through analyzing the genesis and evolution of the CDA, it becomes clear that court interpretations of Section 230 are starkly inconsistent with original Congressional intent, and that the primary way to avoid de facto decriminalization of Internet-facilitated commercial sexual exploitation is to amend the Communications Decency Act.
\end{abstract}

\section{KEYWORDS}

United States, communications decency act (CDA), law, legislative history, sexual exploitation, sex trafficking, craigslist, backpage

$\mathrm{B}$ eginning at age 15, three girls identified as Jane Doe 1, 2, and 3 were sex trafficked through online advertisements. As a result, one girl estimated she was raped 1,000 times, and another estimated she was raped over 900 times. ${ }^{1}$ The website promoting their procurement is well-known among government officials and advocacy groups as a virtual hub for sex trafficking and prostitution. Yet despite existing laws against the procurement or facilitation of sex trafficking and commercial sex, to date these girls remain without justice against the website they consider as the facilitator of their exploitation.

The story of these young women is tragically replicated in the experiences of countless other victims of Internet-facilitated commercial sexual exploitation in America. In the digital age, the commercial sexual exploitation of any person, whether in the form of prostitution or sex trafficking, is easier than ever to achieve. Pimps and traffickers can use online ads to increase the rate at which they sell a given person's body for sex, and sex buyers can shop for a person to sexually use from the comfort of their own home instead of embarking on a risky street walk on the wrong side of town. While procuring or facilitating prostitution and sex trafficking are crimes in America, one law has been interpreted by the courts to grant

${ }^{1}$ Jane Doe No. 1 v. Backpage.com, LLC, 817 F.3d 12, 17 (1st Cir. 2016), cert. denied, 137 S. Ct. 622, 196 L. Ed. 2d 579 (2017). 
broad immunity to websites that facilitate prostitution and sex trafficking so that victims cannot effectively seek recourse and state prosecutors cannot enforce criminal laws against_them. That law is Section 230 of the Communications Decency Act of 1996 (CDA). ${ }^{2}$

The CDA was passed when public use of the Internet was growing in leaps and bounds; and not surprisingly it contained sections that relate to the Internet, including Section 223, which attempted to regulate sexually explicit content on the Internet, and section 230 which created a "safe harbor" for providers and users of interactive computer services (websites) from liability for third party postings. Section 230 of the CDA is the primary law that has been interpreted to immunize websites from culpability for crimes, including trafficking or prostitution, taking place on their platforms.

Until now, most scholarship regarding the CDA has focused on the scope and application of the section 230 immunity from civil liability, primarily regarding defamation cases. ${ }^{3}$ Advocacy groups and legal experts have begun addressing the CDA's impact on sex trafficking and prostitution, but there have not been enough scholarly articles solely dedicated to examining the original intent of the CDA, and its legislative evolution, specifically in relation to its tone-deaf application to cases of commercial sexual exploitation. Although the Communications Decency Act in full context was originally intended to protect children online, the courts have interpreted Section 230, to shield commercial sex exploiters of children and adults alike. This inconsistency is deserving of further academic scrutiny.

The question this paper examines is whether the Communications Decency Act, as it is being interpreted in stark contrast to the original legislative intent, de facto decriminalizes the online provision or procurement of prostituted, and as a consequence, sex trafficked, persons. In order to discuss this question, I provide 1) a critical analysis of the text and original intent of the Communications Decency Act, and 2) an analysis of the way the CDA has been applied in several court cases regarding Internet-facilitated commercial sexual exploitation.

\footnotetext{
${ }^{2}$ Communications Decency Act of 1996, (CDA), Pub. L. No. 104-104 (Tit. V), 110 Stat. 133 (Feb. 8, 1996), codified at 47 U.S.C. $\S \S 223,230$.

${ }^{3}$ See, e.g., Balasubramani, V. (2016). Online intermediary immunity under section 230. Business Lawyer, 72(1), 275-286; Saint, H. (2015). Section 230 of the communications decency act: The true culprit of internet defamation. Loyola Of Los Angeles Entertainment Law Review, (36)1, 39-69; Defterderian, V. (2009). Fair housing council v. roomates.com: A new path for section 230 immunity. Berkley Technology Law Journal, 24(563). https://doi.org/10.15779/Z38QM55 ; Jackson, A. (2009). Cyberspace ... the final frontier: How the communications decency act allows entrepreneurs to boldly go where no blog has gone before. Oklahoma Journal of Law \& Technology, 45(5); Fifer, S., \& Carter, R. (2004). A tale of two safe harbors: The scope of ISP liability and the values of the internet. Journal of Internet Law, 8(2); Hong, L. J. (2004). Batzel v. smith \& barrett v. rosenthal: Defamation liability for third-party content on the internet. Berkeley Technology Law Journal, 19(1), 469-493; Davis, B. (2002). Untangling the publisher versus information content provider paradox of 47 USC $\S 230$ : Toward a rational application of the communications decency act in defamation suits against internet service providers. NML Rev., 32: 75-567; Waldman, B. (1999). A unified approach to cyber-libel: Defamation on the internet, a suggested approach. Richmond Journal of Law and Technology, 6: 9-27.
} 


\section{The Legislative History of the CDA and Analysis of Intent}

In February of 1995, Senators James Exon (D-NE) and Slade Gorton (R-WA) introduced the Communications Decency Act ${ }^{4}$ which was attached in Title $\mathrm{V}$ to the Telecommunications Act of 1996.5 The CDA's primary goal was to protect minors from being exposed to "indecent" or "patently offensive" content online. 6 Title 47 U. S. C. § 223(a)(1)(B)(ii) criminalized the "knowing" publication of "obscene or indecent" material to anyone under 18 years old, and section 223(d) criminalized the "knowing" facilitation of "any comment, request, suggestion, proposal, image, or other communication" that is obscene or child pornography, whether commercial or not. The crafters of the CDA attempted to internally rectify concerns about liability for the Internet industry by providing them with affirmative defenses. Within section 223(e)(5)(A, B) of the CDA, defenses against prosecution for interactive computer services 7 included that the computer service had either taken "in good faith, reasonable, effective, and appropriate actions" to prevent minors from being exposed to explicit content, or has restricted access to the offensive material by "requiring use of a verified credit card, debit account, adult access code, or adult personal identification number." 8 This affirmative defense was designed so that internet service providers attempting to protect children from obscene or indecent materials would not be held liable if in some circumstances those protections failed. However, these "good faith" provisions, which were limited to acts and content, did not go far enough to assuage the technology industry's concerns about free speech and online industry growth.

Section 230 of the CDA was enacted in response to two court cases that concluded with contradictory results. In a 1991 libel case, Cubby, Inc. v. CompuServe, Inc, the defendant website was held not liable for comments posted on its website because it did not review or know about the content. ${ }^{9}$ Later in 1995, Stratton Oakmont, Inc. v. Prodigy Servs. Co., the defendant website was held liable for comments on its virtual bulletin board because the website had moderated and removed some offensive content from comments in the past. ${ }^{10}$ By attempting to moderate some posts, the court declared that the defendant then became liable for all posts. Clearly, this disincentivized websites from establishing any level of moderation, for fear of incurring liability. In response to this Stratton Oakmont case, Representatives Chris Cox (R-CA) and Ron Wyden (D-OR), advanced the addition of

\footnotetext{
${ }^{4}$ Cannon, R. (1996). The legislative history of senator exon's communications decency act: Regulating barbarians on the information superhighway. Federal Communications Law Journal, 49(1), 53. Available at: http://www.repository.law.indiana.edu/fclj/vol49/iss1/3

${ }^{5}$ United States. (1996). Telecommunications Act of 1996. Washington, D.C.: U.S. G.P.O.

${ }^{6}$ Id. Communications Decency Act of 1996.

${ }^{7}$ Interactive computer services are defined by 47 U.S.C. $§ 230(f)(2)$ as "any information service, system, or access software provider that provides or enables computer access by multiple users to a computer server, including specifically a service or system that provides access to the Internet and such systems operated or services offered by libraries or educational institutions."

${ }^{8} 47$ U.S.C. 223(e)(5)(A, B)

${ }^{9}$ Cubby, Inc. v. CompuServe Inc., 776 F. Supp. 135 (S.D.N.Y. 1991).

${ }^{10}$ Stratton Oakmont, Inc. v. Prodigy Services Co., WL 323710 (New York 1995).
} 
section 230 to the Telecommunications Act of 1996 to expand and clarify exemptions from liability. ${ }^{11}$

Subsubsection 230(c)1 of the Communications Decency Act states that: "No provider or user of an interactive computer service shall be treated as the publisher or speaker of any information provided by another information content provider." 12 This provision, however, is part of Subsection (c) which was intended to provide "Protection for 'Good Samaritan' Blocking and Screening of Offensive Material; and Subsection (c) is part of a law (47 U.S.C. 230) which was intended to provide "Protection for private blocking and screening of offensive material." Section 230(c)(2) specifies that these websites are protected from civil liability if the interactive computer service engages in self-regulation or makes "good faith" efforts to edit its website by screening, or restricting, or blocking access to illegal content. 13 This way, the websites would not be subject to liability for editing their website for illegal content but failing to remove all of it, or whenever the website had notice of illegal content, as occurred in Stratton.

Despite the addition of Section 230, as soon as the CDA was passed several plaintiffs filed lawsuits questioning the constitutionality of portions of $\S 223$ (a) and the entirety of $\S 223(d)$. In June of 1996, in the case of American Civil Liberties Union v. Reno, the United States District Court for the District of Eastern Pennsylvania issued an injunction against enforcement of $\S \S 223(\mathrm{a})(1)(B)$ and 223(a)(2) and 223(d) of the CDA. ${ }^{14}$ Additionally, in July of 1996, the Southern District of New York, in Shea $v$. Reno, held that section 223 of the CDA was too broad in its language of "offensive" or "indecent," and that the affirmative defenses set forth in section 223 were either technologically ineffective or would have to rely on third party filtering providers. The court therefore ruled it was unconstitutional as written and agreed that an injunction on enforcement was appropriate. ${ }^{15}$ In December, 1996, the ACLUv. Reno case was appealed to the Supreme Court.

In its appeal to the Supreme Court, the American Civil Liberties Union argued that contested portions of section 223 were unconstitutional under the First Amendment for two reasons: first, that the law is so vague it creates an "obvious chilling effect on free speech;" and second, that because the CDA is a criminal statute the potential severity of punishments-up to two years in prison per act in violation-would likely silence Internet speech. ${ }^{16}$ In 1997, in the case of Reno v. American Civil Liberties Union, the United States Supreme Court invalidated portions of section 223 of the Communications Decency Act on First Amendment grounds. ${ }^{17}$ Section 230 was not at issue in the case and so it remained in place.

In 2003, Congress amended $\S \S 223(\mathrm{a}) \&(d)$ of the CDA. The "indecency" provision was the only provision challenged by the federal courts, and it was eventually

\footnotetext{
${ }^{11} 141$ CONG. REC. H8468-69 (daily ed. Aug. 4, 1995). The Cox/Wyden Amendment was first introduced June 30, 1995. See Center for Democracy and Technology. (Aug. 1, 1995). ALERT: House to Vote This Week on Net-Censorship Bills. 141 CONG. REC. H8468-69 (daily ed. Aug. 4, 1995).

1247 U.S.C. $\S 230$

${ }^{13} 47$ U.S.C. $\$ 230(c)(2)$.

${ }^{14}$ American Civil Liberties Union v. Reno, 929 F. Supp. 824 (E.D. Pa. 1996).

${ }^{15}$ Shea $v$. Reno, 938 F. Supp. 916 (S.D.N.Y. 1996).

${ }^{16}$ Reno v. American Civil Liberties Union 521 U.S. 844 (1997)

${ }^{17}$ Ibid.
} 
struck down in Reno $v$. ACLU. Congress also specified that 223(a) \& (d) now apply to child pornography and obscenity, neither of which are protected by the First Amendment. ${ }^{18}$ When it comes to section 230 of the CDA, however, Courts have held that 230 grants immunity to websites even when the third party posts contain child pornography. ${ }^{19}$ And in 2007, the United States District Court of the Western District of Texas ruled that under the CDA MySpace, a leading social network of the time, was immune to liability for failing to create reasonable barriers to prevent an adult user from contacting, luring, and sexually assaulting a minor user. ${ }^{20}$ This effectively granted CDA immunity to social networking sites as well, even in cases of "gross negligence claims [where] the operator knew that sexual predators were using [the] service to communicate with minors...." ${ }_{21}$

\section{CDA Controversy Over Interpretation and Intent}

The controversy over Section 230 of the Communications Decency Act can be broken down into two parts: the debate regarding broad interpretation of section 230 immunity, and the analysis of this broad interpretation in conjunction with original legislative intent.

Legal interpretation of Section 230 of the Communications Decency Act sparked controversy from its inception, and laid the groundwork for on-going debates regarding the tension between unfettered free speech and online safety. It's important to recognize that the CDA came on the scene in the mid-1990s, nearly simultaneous with the widespread use of the Internet. While the Internet evolved over time, it wasn't until around 1993 that laypersons' usership spiked. ${ }^{22}$ It was only in 1995 that Bill Gates sent his "The Internet Tidal Wave" memo to executive staff members at Microsoft, directing that the Internet should be given the "highest level of importance" for their business. ${ }^{23}$ Section 230 of the Communications Decency Act therefore had substantial impact on the future debate regarding Internet regulation.

On one hand, some scholars embrace court decisions that interpret section 230 of the CDA to effectively instill immutable immunity regarding third party postings. One of the highly cited court cases laying the precedent for this broad interpretation of Section 230 is Zeran v. America Online, Inc. In Zeran, the Fourth Circuit Court of Appeals ruled that Section 230 of the CDA "creates a federal immunity to any cause of action that would make service providers liable for information originating with a third-party user of the service. [emphasis added.]" 24 This

\footnotetext{
${ }^{18}$ United States. (2003). Prosecutorial Remedies and Other Tools to End the Exploitation of Children Today Act of 2003. Washington, D.C.: U.S. G.P.O.

${ }^{19}$ Doe v. Bates: No. 5:05-CV-91-DF-CMC, 2006 WL 3813758, (E.D. Texas, Dec. 27, 2006).

${ }^{20}$ Doe v. MySpace, Inc., 474 F. Supp. 2d 843, 851 n.8 (W.D. Tex. 2007).

21 Ibid.

${ }^{22}$ Cerf, V. (1993). How the internet came to be. The On-line User's Encyclopedia: Bulletin Boards and Beyond. Reading, Massachusetts: Addison-Wesley; Markoff, J. (1993). Business technology: Jams already on data highway. The New York Times. http://www.nytimes.com/1993/11/03/business/business-technology-jams-already-on-data-highway.html?sec=\&spon=\&pagewanted=all

${ }^{23}$ Gates, B. (1995). The internet tidal wave. https://www.justice.gov/sites/default/files/atr/legacy/2006/03/03/20.pdf

${ }^{24}$ Zeran v. AOL, 129 F.3d 327, 330 (4th Cir. 1997), cert. denied, 524 U.S. 937 (1998).
} 
hallmark case paved the way for many other similar court decisions. ${ }^{25}$ To date, the courts have acted as the definitive interpreters and defenders of Section 230 of the CDA. Court rulings and commentators in favor of Section 230 claim that this immunity promotes free speech, particularly in online public forums ${ }^{26}$ and that it encourages self-regulation among interactive computer services because they can monitor their sites without fear of criminal liability. ${ }^{27}$ Courts have also argued that $230(c)(1)$ is important because online websites or companies cannot be expected to have the capacity to review every instance of third-party content uploaded on their platforms. ${ }^{28}$ Cecilia Ziniti in the Berkeley Technology Law Journal, praises Zeran's expansive interpretation of 230(c)(1). She states:

Increased liability on interactive service providers would have negative externalities, be constitutionally problematic and put the brakes on Web 2.0... [without broad CDA immunity as defined by Zeran, websites would face] draining legal battles to which they would react in predictable waysdiminishing the value and promise of Web 2.0. ... Furthermore, depending on how they are implemented, more rigorous ability frameworks would likely impermissibly restrict free speech. ${ }^{29}$

Some scholars believe there should be a type of "cyber-libertarianism" and that "the online environment should ...be permitted to develop its own discrete system of legal rules and regulatory processes" without "the imposition of existing offline legal systems grounded in territorially-based sovereignty." 30 The courts overwhelmingly rule in favor of Internet speech and low regulation. There have been over 300 cases regarding the Section 230 of the CDA, and so far, all "but a handful...find that the website is entitled to immunity from liability." 31

On the other hand, some scholars question the broad interpretation of Section 230, arguing for some level of further responsibility for interactive computer services. $^{32}$ In one Internet libel case involving AOL, Federal District Judge Paul L.

${ }^{25}$ Ben Ezra, Weinstein \& Co. v. America Online, Inc., 206 F.3d 980 (10th Cir.2000); Batzel v. Smith, 333 F.3d 1018 (9th Cir. 2003); Universal Communication Systems, Inc. v. Lycos, Inc., 478 F.3d 413 (1st Cir. 2007); Doe v. MySpace, Inc., 528 F.3d 413, 418 (5th Cir. 2008); Almeida v. Amazon.com, Inc., 456 F.3d 1316, 1321-22 (11th Cir. 2006); Carafano v. Metrosplash.com, Inc., 339 F.3d 1119, 1123 (9th Cir. 2003).

${ }^{26}$ See Zeran v. AOL, Inc., 129 F.3d at 327, 331; Sheridan, D., (1997) "Zeran v. AOL and the effects of Section 230 of the Communications Decency Act upon liability for defamation on the internet." Albany Law Review 61: 178; Ehrlich, P. (2002). Communications decency act $\S 230$. Berkeley Technology Law Journal, 17(1), 401; Thierer, A. (2009). Web 2.0, section 230, and nozick's utopia of utopias. TechLiberation. Retrieved from https://techliberation.com/2009/01/13/web-20-section230-and-nozicks-utopia-of-utopias/

27 See Cox, C. Representative. (August 4, 1995). H8460, H8470, 141 Congressional Record; Goodlatte, R. Representative. (August 4, 1995). H8460, H8471, 141 Con. Rec.

${ }^{28}$ See Zeran, at 333.

${ }^{29}$ Ziniti, C. (2008). The optimal liability system for online service providers: How zeran v. america online got it right and web 2.0 proves it. Berkeley Technology Law Journal, 23(1), 583-616. Retrieved from http://www.jstor.org/stable/24118328

${ }^{30}$ Holland, B. (2008). In defense of online intermediary immunity: Facilitating communities of modified exceptionalism. University of Kansas Law Review, 56, 369, 378.

${ }^{31}$ Hill v StubHub, Inc., 727 S.E.2d 550, 558 (N.C. App.2012).

${ }^{32}$ See, e.g., Bennis, A. (2015). Realism about remedies and the need for a CDA takedown: A comparative analysis of $\S 230$ of the CDA and the U.K. defamation act 2013. Florida Journal of 
Friedman ruled in favor of section 230 immunity, although he felt compelled to note that he disagreed with the common interpretation of section 230. He stated:

In some sort of tacit quid pro quo arrangement with the service provider community, Congress has conferred immunity from tort liability as an incentive to Internet service providers to self-police the Internet for obscenity and other offensive material, even where the self-policing is unsuccessful or not even attempted. 33

It is clear that Section 230 of the CDA, although useful to foster Internet growth and speech, is currently being interpreted in a way that is tone-deaf to its original, contextual purpose. The CDA was intended to protect children online, but ironically it has been interpreted by the courts to shield facilitators of the commercial sexual exploitation of children, as well as adults. Most mainstream websites and forums on the Internet today presumably exercise adequately responsible self-regulation to keep content on their site legal. And most would agree that Facebook should not be held legally responsible for every hateful, injurious comment made during contentious comment-section debates on its platform. However, current interpretations of Section 230 go beyond reasonable distinctions between thirdparty posts and website hosts liability to the point of blindly allowing clearly criminal enterprises to continue operating.

Section 230 was originally created and attached to legislation in intimate conjunction with section 223, which mandated increased responsibility for websites to protect children, not less, and so any interpretation of the CDA that leads to increased sexual exploitation of children is clearly not within Congress's original intent.

In some cases, CDA immunity for websites may appear to hinge on the CDA's assertion that websites, or interactive computer services, should not be "treated as the publisher or speaker of any information" and should therefore not be liable for the criminal consequences. ${ }^{34}$ However, courts should only decide a case based on this language in matters where the crimes specifically involve categories of "publisher" or "speaker," (i.e. defamation, fraud, copyright infringement, etc.,), not in cases about actual criminal conduct like sex trafficking or prostitution. As discussed in a legal research paper from the University of Maryland Francis King Carey School of Law:

International Law, 27(2), 297-331.; Sevanian, A. (2014). Section 230 of the communications decency act: A good samaritan law without the requirement of acting as a good samaritan. UCLA Entertainment Law Review, 21(1), 121-145; Patel, S. (2002). Immunizing internet service providers from third-party internet defamation claims: How far should courts go." Vanderbilt Law Review. 55: 647, 679-689; Freiwald, S. (2000). Comparative institutional analysis in cyberspace: The case of intermediary liability for defamation. Harvard Journal of Law and Technology, 14: 572, 594-596; McManus, B. (2001). Rethinking Defamation Liability for Internet Service Providers. Suffolk UL Rev. 35, 649-650; Goldstein, M. (1999). Service provider liability for acts committed by users: What you don't know can hurt you. John Marshall Journal of Computer \& Information Law, 18, 636637; Spencer, M. (2000). Defamatory email and employer liability: Why razing zeran $v$. america online is a good thing. Richmond Journal of Law and Technology, 6, 25.

${ }^{33}$ Blumenthal $v$. Drudge, supra, 992 F. Supp. 44. at pp. 51-52.

3447 U.S.Code. $§ 230$. 
Many legal theories advanced under the law do not turn on whether a defendant is a "publisher" or a "speaker." Liability for aiding and abetting others' wrongful acts does not depend on the manner in which aid was provided. Designing a site to enable defamation or sex trafficking could result in liability in the absence of a finding that a site was being sued for publishing or speaking. 35

Another court interpretation problem revolves around the fact that section 230 was supposed to be a "Good Samaritan" exemption for websites proactively working to keep their websites clean from indecent or illegal material. Yet unfortunately the current interpretation of Section 230 protects providers who make "no independent effort to identify and remove offensive material" or who fail to remove such material after being notified. ${ }^{6}$ Without the counter-weight of Section 223, Section 230 is being interpreted to effectively lower responsibility and culpability for websites that either intentionally, or with gross negligence, facilitate not only obscenity and child pornography, but even prostitution and sex trafficking.

These current interpretations have obvious consequences when websites are disincentivized from investing serious resources to monitoring their websites for criminal content. As it costs a company time and money to create robust filtering or monitoring systems, it's more economically prudent for a website to simply rely on the effectively guaranteed Section 230 immunity than to police their websites for criminal activity. This broad interpretation of Section 230 has increasingly apparent negative consequences "as more and more criminal activity migrates to the Internet, and the online intermediaries that knowingly host such activity are held immune from traditional modes of checking such lawlessness." 37

For too long, the courts have struggled with the vague language of Section 230, and so "most courts have construed section 230(c)(1) in favor of immunity for interactive websites even in the face of significant personal harm endured by individuals as a result of third-party postings or advertisements." ${ }^{38}$ Although free speech online is a concern for many, the American legal system has long recognized that acts like aiding and abetting should not receive First Amendment protections, even when those acts involve speech of some kind. ${ }^{39}$ Concerns about free speech online must be balanced against concerns about criminal behavior. Websites that not only fail to self-regulate but that also intentionally craft their infrastructure to facilitate crime were never intended to receive blanket immunities under the CDA. As Chief Judge Kozinski wrote, "The Communications Decency Act was not meant to create a lawless no-man's land on the Internet."40

\footnotetext{
${ }^{35}$ Citron, D. K. and Wittes, B. (2017) The Internet Will Not Break: Denying Bad Samaritans Section 230 Immunity. University of Maryland Francis King Carey School of Law, (22), pp. 15

${ }^{36}$ See Barrett v. Rosenthal, 114 Cal. App. 4th 1379, 1395, 1400 (2004).

37 Dyer, R. (2014). The communication decency act gone wild: A case for renewing the presumption against preemption. Seattle University Law Review, 37(837), 862.

${ }^{8} 8$ Ruane, K., \& Tamulus, J. (2010). Congressional Research Service. Communications Decency Act: Section 230(c)(1). R41499.

39 Rice v. Paladin Enters., Inc., 128 F.3d at 242-43 (4th Cir. 1997).

${ }^{40}$ Roommates.com, 521 F.3d. at 1164 (majority)
} 


\section{Virtual Anarchy: Applying the CDA to Cases of Commercial Sexual Exploitation}

The courts have a long history of interpreting Section 230 of the Communications Decency Act to immunize websites from criminal responsibility for behavior that would be criminal if committed offline, as exemplified in the case of the website StubHub.com and claims that it facilitated price-gauging ticket scalping. ${ }^{41}$ Tragically, this application of the CDA is extended beyond mere online retail, to cases of commercial sexual exploitation-defined here to include both prostitution and sex trafficking. Commercial sexual exploitation is a compelling humanitarian crisis that must be given due weight when assessing cases of Internet speech and criminal liability under the CDA. Given the exploitive and harmful effects of commercial sexual exploitation, it is vital the law works to break the chain of supply and demand. Unfortunately, Section 230 of the Communications Decency Act has set a precedent against holding online facilitators of commercial sexual exploitation accountable.

\section{The Ineffective Campaign Against Craigslist}

Craigslist42 is an online classifieds website hosting advertisements for buying, selling, or renting a variety of items and services, from lamps, to cars, to commercial sex. In March of 2005 there were reportedly an average of 25,000 new ads for prostitution every 10 days on Craigslist in the U.S. alone.43 Many sex ads on Craigslist regularly featured "code words that imply domestic trafficking ("here for a short stay," "looking for an inexperienced girl"), or international trafficking (both Mexican and U.S. phone numbers given)." 44 High-profile matters involving Craigslist include a 2011 case where nine men from the Gambino organized crime family of New York were convicted of sex trafficking young women by advertising them on Craigslist, along with other crimes. 45

After increasing public awareness about the prevalent sex ads on Craigslist, Thomas Dart, the Sheriff of Cook County, Illinois, sued Craigslist in 2009 for its role in facilitating prostitution advertisements as posted by third parties within its "Adult Services" website section. The United States District Court for the Northern District of Illinois ruled against Sheriff Dart and declared that Craigslist was immune to liability under Section 230(c)(1) of the Communications Decency Act. ${ }^{46}$

Despite avoiding liability in the Dart case, Craigslist faced increasing public scrutiny and criticism for its prostituted services ads. In September, 2010, 17 state attorneys general requested that Craigslist remove the "Adult Services" segment on its website. That same month, Craigslist was also reprimanded by Members of

\footnotetext{
${ }^{41}$ Hill v. StubHub, Inc., 727 S.E.2d 550 (N.C. Ct. App. 2012)

${ }^{42}$ See http://craigslist.org.

${ }^{43}$ Farley, M. (2006). Prostitution, trafficking, and cultural amnesia: What we must not know in order to keep the business of sexual exploitation running smoothly. Yale J.L. \& Feminism 109, 111 supra note 107.

${ }^{44}$ Farley, M., Franzblau, K., \& Kennedy, M. (2014). Online prostitution and trafficking. Albany Law Review, 77(3), 1074.

${ }^{45}$ U.S. Attorney, S. Dist. of N.Y. (2011). Nine gambino crime family members sentenced in manhattan federal court for racketeering, murder conspiracy, extortion, sex trafficking, and other crimes. Retrieved from http://www.justice.gov/usao/nys/pressreleases/May11/marinodanieletalsentencingspr.pdf

46 Thomas Dart, Sheriff of Cook County v. Craigslist, Inc., 665 F. Supp. 2d 961 (N.D. Ill. Oct. 20, 2009).
} 
the U.S. House Judiciary Committee Subcommittee on Crime, Terrorism and Homeland Security for its role in contributing to the crisis of child sexual exploitation in America. Testimony from Deborah Richardson, Chief Program Officer of the Women's Funding Network, stated that at the time Craigslist received three times the responses for sexual service ads as its nearest mainstream competitor. 47 Craigslist yielded to the political and public pressure to and removed the "Adult Services" section on its website, $4^{4}$ although ads for sexual services have not been expunged from the site but have instead migrated elsewhere to the "personals" or "therapeutic" sections. Ads for commercial sex continue to appear on Craigslist regularly. 49

\section{The Open Secret of Sex Trafficking On Backpage.com}

Backpage.com 50 is an online classifieds website, functioning similar to Craigslist.org. However, what sets Backpage apart from Craigslist is the business model that appears to be constructed primarily around ads for sex, not to mention the fact that Backpage also owns several other websites exclusively dealing in selling sex online. $5^{1}$

Backpage.com claims that it "is committed to preventing those who are intent on misusing the site for illegal purposes." ${ }^{2}$ The website purports to have "implemented strict content policies to prevent illegal activity," and to ensure "inappropriate ad content [is] removed." 53 Backpage.com also requires those who post "adult services" advertisements to click a link indicating they will not "post any solicitation directly or in coded fashion for any illegal service exchanging sexual favors for money or other valuable consideration." 54 However, these measures were unconvincing to 51 Attorneys General (including Guam and American

\footnotetext{
${ }^{47}$ Richardson, D. (2010). Domestic Minor Sex Trafficking Before the H. Comm. on the Judiciary, Subcomm. on Crime, Terrorism and Homeland Security. 111th Cong. 2-3.

${ }^{48}$ Miller, C. (2010). Craigslist says it has shut its section for sex ads. New York Times. Retrieved from http://www.nytimes.com/2010/09/16/business/16craigslist.html

${ }^{49}$ WGME. (2017). Woman, 7 men charged in connection to lengthy prostitution investigation in damariscotta. Retrieved from http://wgme.com/news/local/woman-7-men-charged-in-connection-to-lengthy-prostitution-investigation-in-damariscotta; Detman, G. (2017). Five arrested in prostitution crackdown in west palm beach. Retrieved from http://cbs12.com/news/local/four-arrested-in-prostitution-sting-in-west-palm-beach; The Lincoln County News. (2017). Sheriff's office charges eight in 'extensive' prostitution investigation. Retrieved from http://lcnme.com/currentnews/damariscotta-woman-charged-engaging-prostitution/

${ }^{50}$ See http://backpage.com.

${ }^{51}$ I.e. EvilEmpire.com, NakedCity.com, and BigCity.com. Portman, R., \& McCaskill, C. (2016). Recommendation to Enforce a Subpoena Issued to The CEO Of Backpage.Com, LLC: Staff Report (Unites States Senate). Permanent Subcommittee on Investigations, Committee on Homeland Security and Governmental Affairs. 26-28.

${ }^{52}$ Backpage.com. Safety and Security Enhancements. Retrieved from http://blog.backpage.com/ (2011).

53 Ibid.

${ }^{54}$ See Backpage.com. (2011). Posting Rules, Retrieved August, 2011 from http://posting.seattle.backpage.com/gyrobase/classifieds/PostAdPPI.html/sea/posting.seattle.backpage.com/?section $=4381 \&$ category $=4443 \& u=$ sea\&serverName=posting.seattle. backpage. .com\&superRegion=Seattle. Since Backpage shut down the Adult Services section on its website this page now reads as "censored" at the time of writing (April, 2017). Since Backpage shut down the Adult Services section on its website this page now reads as "censored" at the time of writing (April, 2017.)
} 
Samoa) who signed a letter 55 publicly recognizing the high rates of sex trafficking occurring on Backpage.com.

Backpage has been criticized by advocacy organizations and investigated by a Senate subcommittee for its facilitation of sex trafficking. Organizations combating sexual exploitation like the National Center for Missing and Exploited Children ${ }^{56}$, Shared Hope International ${ }^{57}$, the National Center on Sexual Exploitation ${ }^{58}$, and the Coalition Against Trafficking in Women ${ }^{59}$ have all made public statements denouncing Backpage.com. In fact, in 2015 senior vice president at the National Center for Missing and Exploited Children (NCMEC), Yiota Souras, testified about sex trafficking on Backpage. She spoke at a human trafficking investigative hearing on Backpage, held by the U.S. Permanent Subcommittee on Investigations, stating: "A majority of the child sex trafficking cases reported to NCMEC involve ads posted on Backpage.com. Of all the child sex trafficking reports submitted by members of the public to the CyberTipline, more than seventy-one percent (71\%) relate to Backpage ads." 60 At that same hearing, Backpage CEO, Carl Ferrer, was subpoenaed to testify but failed to appear. ${ }^{61}$

In March, 2016, U.S. Senators filed a civil lawsuit to enforce the subpoena on Ferrer and to require Backpage to turn over relevant documents for the investigation. ${ }^{62}$ This dramatic step was the first time in more than 20 years that the Senate had filed a civil contempt action. ${ }^{63}$ In August 2016, U.S. District Court Judge Rosemary Collyer ordered Ferrer to comply with the Senate subcommittee's subpoena

\footnotetext{
${ }^{55}$ McPherson, J. (2011). Re: Backpage.com's ongoing failure to effectively limit prostitution and sexual trafficking activity on its website. In Archive.org. Retrieved April 2, 2017 from https://archive.org/stream/239593-backpage-letter/239593-backpage-letter_djvu.txt.

${ }^{56}$ National Center on Missing and Exploited Children. (2015). Human trafficking investigation hearing. Retrieved from April 23, 2017. http://www.missingkids.org/Testimony/11-19-15.

${ }^{57}$ Shared Hope International. (2017). Ending online facilitation of domestic minor sex trafficking. Retrieved April 23, 2017 from https://sharedhope.org/what-we-do/bring-justice/ending-onlinefacilitation-dmst/

${ }^{58}$ National Center on Sexual Exploitation. (January 13, 2017). Backpage.com hub of trafficking, prostitution, porn. Retrieved April 23, 2017 from http://endsexualexploitation.org/backpage/

${ }^{59}$ Coalition Against Trafficking in Women. (2017). Retrieved April 23, 2017 from http://www.catwinternational.org/Home/Article/638-catws-global-campaign-for-a-sex-trafficking-free-internetupdate-on-backpage

${ }^{60}$ Souras, Y. G., Sr. V.P. and Gen. Counsel for NCMEC. (2015). Human Trafficking Investigation: Hearing Before the Permanent Subcomm. on Investigations of the Senate Comm. on Homeland Security and Governmental Affairs. S. Hrg. No. 114-179, 114th Cong., 39.

${ }^{61}$ Human Trafficking Investigation. (November 19, 2015). Hearings: Homeland Security \& Governmental Affairs Committee. Retrieved April 04, 2017 from https://www.hsgac.senate.gov/subcommittees/investigations/hearings/human-trafficking-investigation

${ }^{62}$ United States District Court for the District of Colombia. (March 29, 2016). Memorandum of points and authorities in support of application to enforce subpoena duces tecum of senate permanent subcommittee on investigations. Retrieved from https://assets.documentcloud.org/documents/3006305/Backpage-Ruling.pdf

${ }^{63}$ Homeland Security \& Governmental Affairs Committee. (March 29, 2016). Permanent subcommittee on investigations brings civil action against backpage in federal district court. Retrieved April 04, 2017 from https://www.hsgac.senate.gov/subcommittees/investigations/media/permanent-subcommittee-on-investigations-brings-civil-action-against-backpage-in-federal-districtcourt
} 
and hand over documents pertaining to Backpage's business practices. ${ }^{64}$ Upon his appearance at the subcommittee hearing, Ferrer and other Backpage executives pled the fifth, refusing to offer any insight or defense. 65

In 2016, after a three year investigation by the California Attorneys General's office, authorities in Texas arrested Ferrer on felony charges related to pimping on its website. ${ }^{66}$ But the charges were thrown out by a Sacramento Superior County Superior Court judge primarily due to the "immunity" supposedly granted by the Communications Decency Act Section 230, which the judge said "struck a balance in favor of free speech" when it shielded Internet service providers from liability for third party postings, ${ }^{67}$ all this despite the fact that Ferrer had acknowledged that there are ads for child sex trafficking victims on Backpage. ${ }^{68}$

That same year another lawsuit was filed against Backpage.com in Massachusetts. ${ }^{69}$ After initially dismissed on the grounds of the CDA, the case eventually went to the United States Court of Appeals. ${ }^{70}$ This time the case was brought on behalf of three women who were sex trafficked on Backpage as minors. They argued, among other things, that Backpage violated the Trafficking Victims Protection Reauthorization Act (TVPRA) as a party which "knowingly benefits, financially or [sic] receiv[es] anything of value from participation in a venture which that person knew or should have known has engaged in an act" of sex trafficking. ${ }^{71}$ The survivors also argued that Backpage clearly profited from sex trafficking because the "adult entertainment" advertisements were the only advertisements for which Backpage charged a posting fee, and second, users could also pay additional fees for "sponsored ads" to show the image, location, and availability of the advertised person along the side of every page in the "escorts" section. ${ }^{72}$ Further, the California Attorney General's office reported that internal Backpage revenue reports from January 2013-March 2015 revealed that "99\% of Backpage's worldwide income was directly attributable to the "adult" section."73

\footnotetext{
${ }^{64}$ National Center on Missing and Exploited Children. (November 19, 2015). Backpage made a huge mistake today.... Retrieved April 04, 2017 from http://blog.missingkids.com/post/133546916075/backpage-made-a-huge-mistake-today

${ }^{65}$ Madhani, A. (2017). Backpage executives refuse to answer senate panel probing sex trafficking. USA Today. Retrieved April 04, 2017 from https://www.usatday.com/story/news/2017/01/10/ backpage-executives-refuse-answer-senate-panel-probing-sex-trafficking/96390352/

${ }^{66}$ Domonoske, C. (2016). CEO of backpage.com arrested, charged with pimping. NPR. Retrieved April 02, 2017 from http://www.npr.org/sections/thetwo-way/2016/10/07/497006100/ceo-ofbackpage-com-arrested-charged-with-pimping

${ }^{67}$ People of the State of California $v$. Carl Ferrer et al, 14-15 (Superior Court of The State of California County of Sacramento 2016).

${ }^{68}$ AG Letter, supra note 2, at 2 ("In a meeting with the Washington State Attorney General's Office, Backpage.com Vice President Carl Ferrer acknowledged that the company identifies more than 400 "adult services" posts every month that involve minors.")

${ }^{69}$ Doe ex rel. Roe v. Backpage.com, LLC, 104 F. Supp. 3d 149 (D. Mass. 2015), aff'd sub nom; Jane Doe No. 1 v. Backpage.com, LLC, 817 F.3d 12, 17 (1st Cir. 2016), cert. denied, 137 S. Ct. 622, 196 L. Ed. 2d 579 (2017).

${ }^{70}$ Jane Doe No. 1 v. Backpage.com, LLC, 817 F.3d 12, 17 (1st Cir. 2016), cert. denied, 137 S. Ct. 622, 196 L. Ed. 2d 579 (2017).

${ }^{71} 18$ U.S.C. $\S \S 1591,1595(a)$

72 Jane Doe No. 1 v. Backpage.com, Ibid.

${ }^{73}$ State of California, Department of Justice, Office of the Attorney General. (2016). Attorney general kamala d. harris announces criminal charges against senior corporate officers of backpage.com
} 
Advocacy groups and elected officials clearly affirm that Backpage.com knowingly profits from advertising prostituted and sex trafficked persons online. Certainly, no company worth millions of dollars can claim absolute ignorance about its primary source of income, and therefore awareness of the likely illegal acts involved for website sections conspicuously labeled "escorts." Yet the courts have steadfastly granted Backpage immunity.

In the case of Jane Doe 1 et al v. Backpage, the Court of Appeals held that the Communications Decency Act, Section 230, protected Backpage from liability, although it noted the tension between legal imperatives to protect trafficking victims and to provide interactive computer services with immunity, acknowledging that these two principles "do not fit together seamlessly." 74

\section{Inconsistency in the Court's Treatment of Website Participation in the Development of Illegal Content}

CDA immunity is not always guaranteed. For example, a precedent was set in a past ruling against CDA immunity in the case of Fair Housing Council, San Fernando $v$. Roommates.com, which potentially opened the door for holding websites like Backpage.com accountable.

Roomates.com is a website matching individuals searching for and offering spare room rentals. The site was sued by a number of fair housing councils because users were required to answer questions regarding the user's sexual orientation, gender, and family status. These responses became part of the individual's profile, in addition to any user-generated information inserted into an "additional comments" box. The questionnaire and some users' additional comments violated fair housing statutes because they allowed users to discriminate in housing on the basis of sexual orientation, gender, or family status. ${ }^{75}$ When evaluating this complaint, the United States Court of Appeals for the Ninth Circuit initially noted that:

A website operator can be both a service provider and a content provider: If it passively displays content that is created entirely by third parties, then it is only a service provider with respect to that content. But as to content that it creates itself, or is "responsible, in whole or in part" for creating or developing, the website is also a content provider. Thus, a website may be immune from liability for some of the content it displays to the public but be subject to liability for other content. 76

In addition, the Ninth Circuit stated that:

[We] interpret the term "development" as referring not merely to augmenting the content generally, but to materially contributing to its alleged unlawfulness. In other words, a website helps to develop unlawful content,

\footnotetext{
for profiting from prostitution and arrest of carl ferrer, CEO. Retrieved April 29, 2017 from https://oag.ca.gov/news/press-releases/attorney-general-kamala-d-harris-announces-criminalcharges-against-senior

${ }^{74}$ Jane Doe No. 1 v. Backpage.com, Ibid.

${ }^{75}$ Fair Housing Coun., San Fernando v. Roommates.com, 521 F.3d 1157 (9th Cir. 2008).

${ }^{76}$ Roommates, 521 F.3d at 1162-63 (citing Anthony $v$. Yahoo! Inc., 421 F. Supp. 2d 1257, 1262-63 (N.D.Cal.2006), aff'd 376 Fed.Appx. 775 (9th Cir.2010)
} 
and thus falls within the exception to section 230, if it contributes materially to the alleged illegality of the conduct. 77

The Ninth Circuit ultimately held that Roomates.com was not exempt from liability with respect to the specific questionnaire since the website provided those questions and therefore became an information content provider. ${ }^{78}$ Yet the Ninth Circuit also determined that the website retained CDA immunity regarding any information in the "additional comments" box since that text was purely user-generated. This established some precedent for analyzing specific content alleged to be unlawful rather than the entire website.

Unfortunately, this same logic has not yet been applied to Backpage.com's role in developing or aiding illegal content. Three sex trafficking survivors argued that Backpage deliberately structured portions of its website to facilitate sex trafficking, as evidenced by the fact that Backpage "selectively removed certain postings" in the Escorts section, including "postings made by victim support organizations and law enforcement sting advertisements" and that Backpage's posting requirements made trafficking easier. ${ }^{79}$ Further, a report from the Senate Permanent Subcommittee On Investigations found that Backpage installed a specialized filter to remove terms like "lolita, teenage, rape, young, amber alert, little girl, teen, fresh, innocent, and school girl" from posts, and that Backpage's own internal estimates state that the company was either manually or automatically editing up to 70-80\% of the ads in the "adult" section by late-2010. ${ }^{80}$ Although the court held that these constituted simple monitoring practices protected under the CDA, it could be argued that these activities fall within "development" of illegal activities, which in the past negated CDA immunity.

In the case of Jane Doe 1 et al. v. Backpage, the First Circuit made it clear that even claims alleging that Backpage was designed to facilitate illegal conduct are precluded by the CDA since such claims "necessarily treat the website as a publisher or speaker of content provided by third parties." ${ }^{11}$ In contrast with the Ninth Circuit's Fair Housing Council decision, the First Circuit soundly rejected the plaintiffs' "core argument" that Backpage was not entitled to CDA protection because it had "tailored its website to make sex trafficking easier." ${ }^{2}$ Although the Fair Housing Council case held the website responsible for tailoring its website in a way that fostered illegal activity (i.e. housing discrimination based on sexual

\footnotetext{
${ }^{77}$ Roommates at $1167-68$

${ }^{78}$ Roommates at 1166

${ }^{79}$ Jane Doe No. 1 v. Backpage.com, Ibid: "For example, Backpage does not require phone number verification and permits the posting of phone numbers in alternative formats. There is likewise no e-mail verification, and Backpage provides users with the option to "hide" their e-mail addresses in postings, because Backpage provides message forwarding services and auto-replies on behalf of the advertiser. Photographs uploaded for use in advertisements are shorn of their metadata, thus removing from scrutiny information such as the date, time, and location the photograph was taken. While Backpage's automated filtering system screens out advertisements containing certain prohibited terms, such as 'barely legal' and 'high school,' a failed attempt to enter one of these terms does not prevent the poster from substituting workarounds, such as 'brly legal' or 'high schl."'

${ }^{80}$ U.S. Congress, Senate, Committee on Homeland Security and Governmental Affairs, Permanent Subcommittee on Investigations, Backpage.com's knowing facilitation of online sex trafficking, 114 Cong. 2.

${ }^{81}$ Op. at 19.

${ }^{82}$ Op. at 37.
} 
orientation or family status), the Courts did not extend this logic to the Adult or Escort section of Backpage. In the case of Backpage, the Court concluded by explaining that "Congress did not sound an uncertain trumpet when it enacted the CDA, and it chose to grant broad protections to internet publishers." 83 Thus, even "showing that a website operates through a meretricious business model"-such as facilitating the victimization of underage young women through sex trafficking"was not enough to strip away" the protections afforded by the CDA. ${ }^{84}$

\section{Discussion: How the CDA Immunizes Illegal Activity and the Obstacles to Change}

It is clear from the legislative history of the Communications Decency Act that the broad immunity now provided by section 230 as a result of Court decisions exemplified in the decisions regarding cases of sexual exploitation cases against Craigslist and Backpage-is in conflict with the original purpose of the CDA and instead de facto decriminalizes the online provision and facilitation of prostitution, which then creates a more easily accessible marketplace for sex traffickers as well. In fact, research shows that across 150 countries, on average, "countries where prostitution is legal experience larger reported human trafficking inflows." 85

Without the loophole of Internet immunity, websites that facilitate advertisements for prostitution and sex trafficking, and therefore profit from the ad posting or clicks, would clearly be breaking the law for facilitating the procurement of both trafficked and prostituted persons.

The Trafficking Victims Protection Act (TVPA) is the primary federal law on human trafficking. It defines severe forms of trafficking to include "sex trafficking in which a commercial sex act is induced by force, fraud, or coercion, or in which the person induced to perform such act has not attained 18 years of age." 86 The elements comprising the three-part sex trafficking process are acts, means, and purpose. The acts include "recruiting, enticing, harboring, transporting, providing, obtaining, advertising, maintaining, patronizing or soliciting," and the means include the use of force, threat of force, fraud, or coercion. ${ }^{87}$ The purpose is defined by the Trafficking Victims Protection Act (TVPA) as "to cause the person to engage in a commercial sex act." 88 Under these definitions it is therefore a crime to provide a minor-even in the absence of force, fraud of coercion-for the purpose of commercial sexual exploitation or to provision an adult by threats of force, fraud, or coercion.

Prostitution is typically defined to mean "the act of offering one's self for hire to engage in sexual relations" and it is illegal in all U.S. states except for Nevada where it is regulated in a few specific counties. ${ }^{89}$ Most states have laws against

\footnotetext{
${ }^{83}$ Ibid.

${ }^{84}$ Ibid.

${ }^{85}$ Cho, S-Y., Dreher, A., \& Neumayer, E. (January 16, 2012). Does legalized prostitution increase human trafficking? World Development, 41(1), 67-82. Available at SSRN: https://ssrn.com/abstract=1986065 or https://doi.org/10.2139/ssrn.1986065

86 TVPA, 22 U.S. Code \$1702(9).

${ }^{87} 18$ U.S.C. $§ 1591(a)$.

${ }^{88}$ Ibid

${ }^{89}$ Farlex. (2017). Prostitution. The Free Dictionary. Retrieved April 29, 2017 from http://legal-dictionary.thefreedictionary.com/Prostitution
} 
pimping or pandering to facilitate prostitution, such as the California penal code which states that any person who "receives or gives, or agrees to receive or give, any money or thing of value for procuring, or attempting to procure, another person for the purpose of prostitution" is guilty of pandering, a felony punishable with imprisonment for up to six years. ${ }^{90}$ In Colorado the code states that pandering includes anyone "knowingly arranging or offering to arrange a situation in which a person may practice prostitution."91 Similar definitions addressing pandering in the form of facilitating, or arranging a situation where a person can practice prostitution are offered by other states as well. ${ }^{22}$ Common legal definitions for procurement include making a person available for purposes of commercial sex.93 Therefore, websites that post ads for prostituted persons facilitate their availability, and could therefore face liability for procurement and pandering.

The laws surrounding prostitution and sex trafficking have failed to adapt to technological advances, or to recognize the prevalence of these crimes online. Actions that are categorically criminalized on the street are now protected as expressions of free speech because they take place on the Internet.

Although there is growing awareness around the problem of sex trafficking on Backpage.com, significant political will is necessary to cultivate any meaningful legislative change in the face of powerful opposition by ACLU-style free speech libertarians and the self-serving technology community.

The technology community's reaction to the original Communications Decency Act, Section 223, was swift and forceful. Immediately after the CDA was passed through Congress on February $1^{\text {st }}, 1996$, the Electronic Frontier Foundation (EFF) made a statement against it due to fear of Internet regulation and launched a Blue Ribbon Campaign ${ }^{94}$ urging individual websites to display blue ribbons and link back to the EFF website as a sign of solidarity. The EFF later claimed that the Blue Ribbon Campaign page became the fourth most linked-to website on the Internet during that time period.95 Once President Clinton signed the bill into law on February $8^{\text {th }}$, the New York Times documented that thousands of websites went dark for 48 hours in protest. ${ }^{6}$ This was purportedly the first web blackout protest, and it united digital interest groups like Electronic Frontier Foundation, Center for Democracy \& Technology, Electronic Privacy Information Center, along with "the

\footnotetext{
${ }^{90}$ C.A. Penal Code $\S 266 i(6)$

${ }^{91}$ C.O. Criminal Code, Title $18 \S 18-7-203$ (1)(b).

${ }^{92}$ I.L. Criminal Offenses, Chapter $720 \S 5 / 11-14.3$ (a)(b); N.E. Revised Statutes, Chapter $28 \S 28-$ 802 (1)(d); W.I. Statutes Crimes (Ch. 938 to 951) § 944.33 (2); D.C. Code Division IV § 22-2705 (a)(1); N.Y. Penal Law $\S 230.15$ (1-2); F.L. Statutes Title XLVI. Crimes $§ 796.07$ (2) (b,f,h); O.R. Revised Statutes Crimes and Punishments $§ 167.012$ (a,c); V.T. Statutes Title 13. Crimes and Criminal Procedure, $\S 2632$ (a)(1,6).

${ }^{93}$ Lehman, J., \& Phelps, S. (2008). West's Encyclopedia of American Law, 2nd Ed. Detroit: The Gale Group, Inc.

${ }^{94}$ EFF Statement on 1996 Telecommunications Regulation Bill. (1996). Your constitutional rights have been sacrificed for political expediency. Internet Archive. Retrieved April 14, 2017 from http://web.archive.org/web/19971114041326/www.eff.org/pub/Alerts/cda_020296_eff.statement

${ }^{95}$ Higgins, P. (2016). The web's first blackout protest: The CDA, 20 years later. Electronic Frontier Foundation. Retrieved April 15, 2017 from https://www.eff.org/deeplinks/2016/02/webs-firstblackout-protest-cda-20-years-later

${ }^{96}$ Lewis, P. (1996). Protest, cyberspace-style, for new law. The New York Times. Retrieved from http://www.nytimes.com/1996/02/08/us/protest-cyberspace-style-for-new-law.html
} 
National Campaign for Freedom of Expression, National Coalition Against Censorship, People for the American Way, Feminists for Free Expression, and the National Gay And Lesbian Task Force, as well as businesses such as The Well and Wired." 97 The U.S. Supreme Court decision ruling section 223 of the CDA unconstitutional was heralded widely as a victory by the technology community, and current day media and tech industry giants, such as the American Society of News Editors, Yelp Inc., and Google, continue to lobby and file suites appealing to, and supporting, Section 230 immunity of the Communications Decency Act. ${ }^{8}$

Given the influence of the technology community on policy-makers, both through monetary contributions to political campaigns and online demonstrations such as the one conducted in 1996, understanding the harms of immunity for Internet-facilitators of sexual exploitation is more important than ever if the political and public interest is to ever grow strong enough to create substantive change.

\section{Conclusion: Next Steps}

This paper is one of few reviews to provide a critical analysis of the Communications Decency Act in conjunction with the far-reaching implications of protecting the facilitation of procurement of sexually trafficked and prostituted persons caused by the CDA's current application. After a critical analysis of the original text of the CDA, it is clear that Section 230 has been severed entirely from the contextual purpose of the CDA, so that the online facilitators of sex trafficking and prostituted persons are immune from conviction.

Moving forward, in order to remedy the incongruence between the legality of facilitating commercial sex acts in-person versus online, it is vital to amend Section 230 of the Communications Decency Act. The history of Craigslist and Backpage show that in the vacuum of legal deterrents, exploitive entrepreneurs will continue to create new websites to profit from the proven market for adults and children sexually exploited and trafficked into sex. At the time of writing there are two bills on Capitol Hill, the Stop Enabling Sex Traffickers Act of 2017 (S.1693), and Allow States and Victims to Fight Online Sex Trafficking Act of 2017 (H.R.1865) which seek to amend the CDA. As both move forward through amendments and revisions, it is important for final versions to incorporate strong language against websites that knowingly, or with reckless disregard, facilitate trafficking if there is any hope to shrinking the online market for sex.

\footnotetext{
${ }^{97}$ Higgins, Parker. Ibid.

${ }^{98}$ Lobbying Report: American Society of News Editors. (2013). LD-2 Disclosure Form. Retrieved April 15, 2017 from https://soprweb.senate.gov/index.cfm?event=getFilingDetails\&filingID=AFDC1DCA-CDCF-4B12-8BA9-10A327816BB4\&filingTypeID=69; Lobbying Registration: Yelp Inc. (2013). LD-1 Disclosure Form. Retrieved April 15, 2017from https://soprweb.senate.gov/index.cfm?event=getFilingDetails\&filingID=1c6d6cde-f6fa-4be0-be2a-aaa40070b17a\&filingTypeID=1; Weiss, D.C. (2015). Google seeks to enforce subpoenas for communications between jenner lobbyists and state AG. ABA Journal. Retrieved April 15, 2017 from http://www.abajournal.com/news/article/google_seeks_to_enforce_subpoenas_for_communications_between_jenner_lobbyis/
} 
For the women and men, adults and children, who are being sexually exploited and raped even this very day, it is vital to hold websites accountable for their role in this chain of crime. While the Internet is a useful tool, used by many for good and deserving of many basic protections, blanket immunity in the face of human suffering cannot be tolerated.

Every Jane or John Doe deserves justice against those who helped promote and who profited from their exploitation. It's time for the law to begin protecting the victims, not the perpetrators.

\section{ACKNOWLEDGMENTS}

I thank my family and colleagues at the National Center on Sexual Exploitation for their continued support. Dignity thanks the following people for their time and expertise in reviewing this article: Mary Graw Leary, Professor of Law, The Catholic University of America; Christopher R. Green, Associate Professor of Law and H. L. A. Hart Scholar in Law and Philosophy, University of Mississippi School of Law; and Donna Rice Hughes, CEO and President of Enough Is Enough, USA.

\section{AUTHOR BIOGRAPHY}

Haley Halverson is the Vice President of Advocacy and Outreach at the National Center on Sexual Exploitation where she develops and executes national campaigns to improve corporate policies and raise public awareness. Haley regularly speaks on college campuses and writes on topics including child sexual abuse, sex trafficking, prostitution, sexual objectification, the exploitation of males, and more. She has presented before officials at the United Nations, as well as at several national symposia before influencers from the Department of Justice, the Federal Bureau of Investigations, and the Department of Health

and Human Services. She is currently pursuing a Master of Arts at Johns Hopkins University.

\section{RECOMMENDED CITATION}

Halverson, Haley C. (2018). The Communications Decency Act: Immunity for Internetfacilitated commercial sexual exploitation. Dignity: A Journal of Sexual Exploitation and Violence. Vol. 3, Issue 1, Article 12. https://doi.org/10.23860/dignity.2018.03.01.12. 